УДК 330.341.1: 634

DOI: https://doi.org/10.37320/2415-3583/11.13

Колокольчикова I.B.

кандидат економічних наук, доцент, докторант, Полтавська державна аграрна академія

ORCID: https://orcid.org/0000-0002-5692-0901

\title{
МЕХАНІЗМ РЕАЛІЗАЦІЇ НТП У БІЗНЕС-СЕРЕДОВИЩІ РИНКУ ПЛОДОВО-ЯГІДНОї ПРОДУКЦІї
}

\begin{abstract}
Умовою розвитку галузі виробництва високоякісної плодово-ягідної продукиії є впровадження досягнень науково-технологічного прогресу. Обтрунтовано, щүо наукові розробки є важлливим для галузі, вони дають змогу оптимально використовувати природно-кліматичний, біологічний та технологічний потенціал регіонів. Розглянуто стадії реалізації інноваційних нововведень. Окреслено основні види інновацій: біологічні, технічні, хімічні та технологічні. Запропоновано механізм реалізації НТП та взаємодії з бізнес-середовищем на ринку плодовоягідної продукиї. Підкреслено важливість спеціальних установ та держави у підтримиі і реалізації наукового прогресу. Запропоновано розиирити внутрішнє середовище інноваційних перетворень інформаційно-консультаційною, науково-методичною та органічною складовими частинами. Встановлено, щзо саме вони необхідні представникам малого бізнесу, які сьогодні виробляють більщу частину плодів та ягід і мають значні труднощі в отриманні інформації, знань щзодо інновачій, їх упровадження. Визначено, щзо розвиток органічного виробниичтва продукиї доцільно починати з невеликих господарств із метою поступового нарощування обсягів, розвитку внутрішнього ринку та формування попиту.
\end{abstract}

Ключові слова: науково-технічний прогрес, інновачія, державна підтримка, ринок плодово-ягідної продукиії, бізнес-середовище.

Постановка проблеми. Галузь садівництва потребує значних інвестицій, тому що розвиток НТП має на неї суттєвий вплив. Поширення нововведень повинно проходити постійно, однак у галузі воно стримується багатьма факторами. У виробників відсутні вільні кошти на оновлення виробничих процесів. Господарства населення, які зараз виробляють більшу частину плодовоягідної продукції, поряд із низькою товарністю не мають виходу на ринки збуту, у них практично відсутня інформаційна та науково-методична підтримка. Із цих же причин малий бізнес не може реалізовувати ідеї органічного виробництва, хоча має великий потенціал. Ось чому під час реалізації наукових досягнень важливими $є$ інформаційно-консультаційна, науково-методична підтримка виробників як складник самого процесу створення інновацій. I в ринкових умовах органічне виробництво як нова ніша, новий сегмент $\epsilon$ великою конкурентною перевагою. Тому лише взаємодія всіх базових складників наукового прогресу та додаткових ланок підвищать загальний економічний ефект від інноваційних перетворень.

Аналіз останніх досліджень і публікацій. Питання розвитку науково-технічного прогресу завжди розглядаються у симбіозі 3 розвитком відповідної галузі. У садівництві на ці аспекти звертають увагу такі українські науковці, як Л.О. Барабаш [1], С.І. Рудиця [3], які вказують на важливість наукового підходу. Л.О. Болтянська, Л.О.Андрєєва, О.І. Лисак [2], А.М. Пивовар та П.В. Пивовар [4] аналізують вплив базових складників НТП на розвиток галузі. Однак ці наукові підходи не зовсім відображають сучасні реалії, за якими більша частина виробництва плодово-ягідної продукції знаходиться у господарствах населення. Ця особливість значно ускладнює сам процес запровадження нововведень у господарствах малого сектору, бо останні не мають ані коштів, знань, інформації, навичок, ані усвідомленої потреби щодо впровадження нововведень. Тому запропонований нами механізм і $є$ спробою усунення невирішених питань у ситуації, що склалася.

Мета статті полягає в аналізі зовнішнього та внутрішнього середовища реалізації НТП суб'єктів ринку плодово-ягідної продукції, а також виділенні тих складників, які чинять найбільший вплив або не були досі запроваджені.

Виклад основного матеріалу. Науково-технічний прогрес реалізується через наукові та інноваційні нововведення у всіх сферах господарської діяльності. Для виробництва сільськогосподарської продукції важливими $є$ саме наукові розробки, бо їх упровадження приводить до росту продуктивності культур під час використання оптимальних умов природно-кліматичного, біологічного та технологічного потенціалів. Для галузі садівництва цей процес особливо важливий. Л.О. Барабаш акцентує увагу на тому, що роблять наукові інститути у галузі садівництва, зазначаючи, що «в Інституті садівництва (IC) НААН та дослідних установах його мережі проводиться значна робота щодо підвищення конкурентоспроможності галузі, розвитку інноваційної діяльності. Завершені розробки інституту i його дослідних станцій стосуються створення 
та обгрунтування адаптованого сортименту плодових і ягідних культур, що відповідає вимогам інтенсивного садівництва, вирішення питань вирощування оздоровленого садивного матеріалу, розроблення технологій виробництва, зберігання та переробки плодів і ягід, економіки галузі» [1, с. 13]. Зрозуміло, що не лише технологічні аспекти $€$ вирішальними у досягненні кінцевих результатів. Якщо підходити до питання комплексно, то науково-технічний прогрес поширюється через електронізацію, комплексну автоматизацію, створення та використання нових матеріалів, освоєння принципово нових технологій, прискорення розвитку біотехнологій [2, с. 332].

Щодо змісту самого процесу створення та впровадження інновацій, C.I. Рудиця розглядає етапи реалізації цієї діяльності в садівництві, вказуючи на те, що, як і загалом у сільському господарстві, перші стадії інноваційного процесу - дослідження та розроблення - проходять у спеціалізованих наукових установах, а освоєння інновацій здійснюється безпосередньо в сільськогосподарських підприємствах. У сфері аграрного виробництва інновації поділені на чотири види: біологічні (нові сорти, гібриди плодових та ягідних культур із більшим біологічним потенціалом і кращими господарськими ознаками тощо), технічні (нові засоби механізації та автоматизаціі), хімічні (нові засоби захисту садів і ягідників від хвороб та шкідників, мінеральні добрива та гербіциди) і технологічні (нові виробничі, управлінські та інформаційні технологіï) [3, с. 191]. А.М. Пивовар та П.В. Пивовар у авторській моделі впровадження результатів НТП в аграрній сфері розглядають цей процес лише у трьох площинах: технічній, технологічній та біологічній, а також організаційного процесу як фактору забезпечення ix упровадження й ефективності використання. На їхню думку, матеріально-технічна база, а саме техніка, яка працює на виробництві та збиранні врожаїв, є вирішальною в отриманні високих результатів [4, с. 110].

Погоджуємося 3 цими науковцями в тому, що реалізація перетворень у галузі повинна розглядатися у всіх вище перелічених площинах. Однак, на нашу думку, у процесі реалізації науково-технічного потенціалу цю площину необхідно розширити, виділивши «інформаційно-консультаційну», «науково-методичну» та «органічну» складові частини. Таким чином, механізм реалізації науково-технічного прогресу у галузі садівництва під час виробництва, збереження, переробки та продажу плодово-ягідної продукції буде мати такий механізм та форму взаємодії складників цього процесу та зовнішнього середовища, за якого всі учасники отримають відповідний ефект (рис. 1).

Сам по собі науково-технічний прогрес неможливий без зовнішнього впливу, за рахунок якого

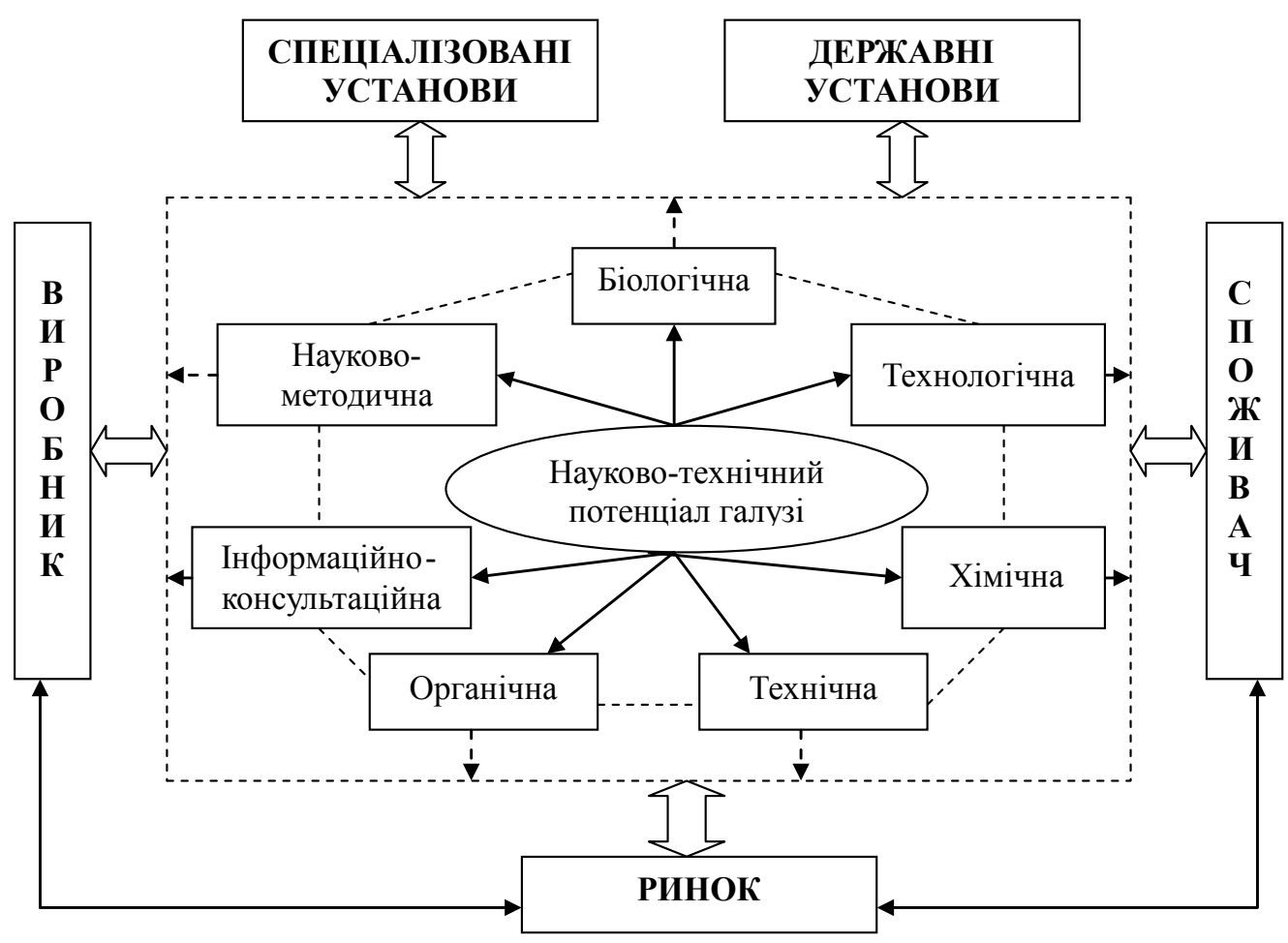

Рисунок 1 - Механізм реалізації НТП та взасмодії з бізнес-середовищем на ринку плодово-ягідної продукції

Джерело: складено автором 
відбувається інноваційний процес. На нашу думку, його складниками, які запускають механізм створення та реалізації нововведень під час виробництва якісної плодово-ягідної продукції, $€$ : державні та спеціалізовані установи, а також ринок як сукупність виробників, продавців та споживачів продукції.

Державні установи працюють над створенням сприятливих умов щодо ведення бізнесу, проведенням наукових досліджень, реалізацією правової та фінансової підтримки господарюючих суб'єктів, а також цільових програм розвитку виробничих напрямів та галузей. Реалізація державних програм у межах галузей АПК фінансується за рахунок коштів Державного бюджету. Однак, як зазначає I.I. Конєва, «однією з проблем розвитку сільськогосподарського виробництва в Україні $є$ його недостатня державна підтримка. Сучасний вплив держави на галузі АПК характеризується недосконалістю, необгрунтованістю та недофінансуванням, що потребує перегляду форм і методів державної підтримки агропромислового комплексу [5, с. 802].

Для галузі садівництва та розвитку ринку плодово-ягідної продукції важливою $\epsilon$ реалізація цільових програм. Саме вони сприяють поширенню інновацій, у тому числі за рахунок бюджетної підтримки. Так, Галузева програма «Плоди і ягоди України - 2017» визначає, що «потреба в інвестиціях на створення насаджень на період до 2017 р. становить 2,3 млрд грн., в тому числі на закладання - 1,1 млрд грн., на догляд до вступу в плодоношення - 1,2 млрд грн. [6]. За Галузевою програмою розвитку садівництва України на період до 2025 року «потреба в інвестиціях на створення насаджень на період до 2025 р. становить 21,1 млрд грн., в тому числі на закладання - 9,2 млрд грн.; на догляд до вступу в плодоношення - 11,9 млрд грн.» [7]. Тобто ці Програми $\epsilon$ комплексною підтримкою виробників плодовоягідної продукції з боку як наукових установ, так і держави. В кожній із них також «передбачається забезпечення потреби в коштах за рахунок прибутку та амортизаційних відрахувань садівничих підприємств, залучених коштів, у тому числі іноземних інвестицій, кредитів, коштів Державного бюджету. У перспективі передбачається поступовий перехід галузі на повне самофінансування, що можливо за умов підтримки розвитку промислового садівництва $з$ боку державних та приватних структур» [6;7].

Порядок використання державних коштів регламентує Урядова програма фінансової підтримки розвитку садівництва, виноградарства та хмелярства через Постанови «Про затвердження Порядку використання коштів, передбачених у державному бюджеті для фінансової підтримки сільгосптоваровиробників»; «Про затвердження
Порядку використання коштів, передбачених у державному бюджеті для розвитку виноградарства, садівництва і хмелярства» [8].

Другий блок зовнішнього середовища, що впливає на реалізацію НТП,_становлять спеціалізовані установи, які займаються розробленням інноваційних продуктів. Мета їньої взаємодії - це створення інноваційних розробок, можливість перевірки їх у реальних виробничих умовах, визначення запитів на нововведення 3 боку виробників, споживачів та ринку загалом. До складу спеціалізованих установ входять: науково-дослідні інститути 3 технологічними лабораторіями, дослідними станціями та господарствами; заклади вищої освіти, особливо аграрного напряму, які, маючи відповідні кафедри, лабораторії, працюють над науковими розробками, отримують патенти на винаходи та авторські свідоцтва, пишуть та захищають наукові праці.

В Україні головною науково-дослідною установою, яка акумулює всі знання та напрацювання у галузі садівництва, $є$ Інститут садівництва національної академії аграрних наук (IC НAAH). До структурних підрозділів Інституту входять відділи та лабораторії, що працюють над винаходами та апробаціями нововведень у галузі садівництва [9].

Великий внеок $\mathrm{y}$ розвиток промислового садівництва Півдня України зробили наукові та виробничі структурні підрозділи, що зосереджені в цьому регіоні. Зокрема, Мелітопольська дослідна станція садівництва імені М.Ф. Сидоренка IC НААН. У іiї структурі є відділи: селекції і сортовивчення; агротехніки; зрошення й агрохімічних досліджень; економіки, інтелектуальної власності і маркетингу інновацій та лабораторія агрохімії. До послуг, що пропонує цей структурний підрозділ Інституту садівництва, відносять: проведення наукової експертизи якості та родючості грунтів на підставі комплексного агрохімічного обстеження; визначення придатності різних типів грунтів для вирощування сільськогосподарських культур iз метою отримання високих врожаїв екологічно чистої продукції; проведення хімічних аналізів грунтів, грунтових і дренажних вод, поливної і дистильованої води, рослин, органічних і мінеральних добрив за 37 параметрами; діагностику мінерального живлення плодових, ягідних, овочевих, зернових, технічних та інших культур; розроблення оптимальних систем удобрення сільськогосподарських рослин з урахуванням їхніх особливостей, грунтових умов, забезпеченості мінеральними й органічними добривами, а також рівня планованої врожайності [9]. В Одеській області працює Національний науковий центр «Інститут виноградарства і виноробства імені В.С. Таїрова», який займається виведенням та впровадженням нових сортів, інтенсивних технологій виробництва плодово-ягідної продукції [10]. 
Якісні результати роботи досягаються шляхом взаємодії всіх структурних ланок. Так, у 2017-2019 рр. Українським інститутом експертизи сортів рослин укладено угоди про творчу співпрацю 3 науково-дослідними установами НААН та НАН (33), вищими навчальними закладами аграрного профілю (22), іноземними установами (32), іншими (3) [11].

Ринок, який уособлює в собі виробників, продавців та споживачів плодово-ягідної продукції, $\epsilon$ по суті головним замовником та споживачем нововведень. Виробники потребують кращих технологій виробництва, обробки, зберігання та транспортування продукції. Продавці (виробники, посередники та торговельна мережа) ставлять вимоги щодо якості та кількості продукціï, можливих термінів зберігання, пакування та транспортування. Споживачі висувають усе нові вимоги до асортименту та якості продукції, формуючи ринковий попит. Тим самим цей блок зовнішнього впливу на розвиток, поширення та реалізацію НТП формує найбільшу потребу в інноваційних розробках.

Внутрішнє середовище реалізації науково-технічних розробок, на нашу думку, повинно бути більш багатогранне: окрім базових складових частин (біологічної, технологічної, хімічної та технічної), які, по суті, створюють інноваційний продукт, ринок вимагає додаткової надбудови. Вимоги сьогодення, а саме виробництво більшої частини продукції господарствами населення, зумовлюють необхідність існування таких складових частин: органічного виробництва, інформаційно-консультаційної підтримки та науковометодичного забезпечення.

Сьогодні $є$ значні результати впровадження інноваційних продуктів у галузі садівництва. Наприклад, у південному регіоні інститутом зрошуваного садівництва за період існування станції виведені понад 250 і районовані 93 сорти плодових культур. Сорти селекції проходять виробниче випробування у Франції. Підвищений інтерес проявляють до них Німеччина, Польща, низка країн СНД, Канада і Болгарія [9]. Нові технології виробництва плодів та ягід придатні до використання не лише у промисловому садівництві, а й у малому бізнесі (власниками підсобних господарств товарного типу). Технічна складова частина реалізується через представлення комплексів машин для механізації технологічних операцій 3 вирощування плодів, ягід та садивного матеріалу. Багато напрацювань $є$ й у напрямі інтенсивних технологій виробництва продукції галузі.

Додаткові структурні надбудови механізму реалізації нововведень у галузі садівництва зумовлені реаліями сьогодення, а саме суттєвим збільшенням виробництва плодів та ягід у господарствах населення. Ці представники малого біз- несу не мають великих площ багаторічних насаджень, а також можливостей аналізувати ринок. Вони останні впроваджують нововведення (бо не завжди про них знають або не розуміють, як це зробити та чи буде ефект за незначних обсягів виробництва). Власники підсобних господарств відчувають складнощі і з реалізацією своєї продукції. Ось чому інформаційно-консультаційна та науково-методична складові частини $є$ необхідними. Це саме такі структурні надбудови, які забезпечать власників невеликих підсобних господарств та фермерів ринковою інформацією про нововведення; про те, як правильно в науковометодичному плані їх реалізувати та розрахувати ефект; про ринкову ситуацію (попит і пропозицію); вимоги торговельних підприємств тощо.

Органічне виробництво також доцільно розвивати через малий бізнес, тому що за умов спеціальних підходів до технології виробництва продукції це простіше зробити не промисловому садівничому підприємству, а невеликому (забезпечуючи максимальний догляд та дотримання технологічних вимог). Поступовий шлях до формування попиту на органічну продукцію вимагає $\mathrm{i}$ поступового розвитку внутрішнього ринку.

Висновки. Підсумовуючи все вищесказане, можна дійти висновку про те, що в сучасних ринкових умовах науково-технічний прогрес займає центральне місце та прямо впливає на ринок плодово-ягідної продукції. Завдяки науковим розробкам та зростаючим запитам споживачів механізм реалізації інновацій можливий лише за умов взаємодії зовнішнього та внутрішнього середовища. Держава має відігравати вирішальну роль у підтримці цього процесу, рскільки галузь садівництва потребує значних інвестицій. Внутрішній механізм створення та реалізації наукового прогресу неможливий без інформаційно-консультаційної та науково-методичної складових частин. Це є значною допомогою у просуванні нововведень саме представниками малого бізнесу, які нині виробляють більшу частину плодово-ягідної продукції, однак не мають можливостей їі ефективно реалізувати. Також реаліями сьогодення $\epsilon$ і розвиток ринку органічної продукції, яку в галузі садівництва доцільно розвивати та нарощувати через малі підприємства. Це дасть можливість поступово збільшити обсяги виробництва органічних плодів та ягід, сформувати попит на цю продукцію, дати поштовх до подальшого розвитку внутрішнього ринку органічної продукції. Взаємодія всіх складників механізму реалізації науково-технічного прогресу у підсумку дає можливість прискорити впровадження інновацій у виробничий сфері великого, середнього і малого бізнесу, а також досягти високої якості продукції і відповідного економічного ефекту. 


\section{Список використаних джерел:}

1. Барабаш Л.О. Стратегія інноваційного розвитку галузі садівництва. Збірник наукових праць ВНАУ. Серія: Економічні науки. 2012. № 3(69). С. 10-14.

2. Болтянська Л.О., Андрєєва Л.О., Лисак О.І. Економіка підприємства: навчальний посібник. Херсон: Олді-плюс, 2015. $668 \mathrm{c}$.

3. Рудиця С.І. Роль інновацій у підвищенні ефективності промислового садівництва. Збірник наукових праць ВНАУ. Серія: Економічні науки. 2012. №3(69). С. 190-194.

4. Пивовар А.М., Пивовар П.В. Вплив НТП на процеси формування та ефективності використання машинно-тракторного парку сільськогосподарських підприємств. Вісник ЖНАЕУ. 2015. № 1 (48). Т. 2. С. 105-116.

5. Корнєва I.I. Державна фінансова підтримка підприємств АПК: стан та стратегія розвитку. Глобальні та національні проблеми економіки: Електронне наукове видання. 2016. B.14. C. 802-807. URL: http://global-national.in.ua/ archive/14-2016/160.pdf (дата звернення: 06.05.2020).

6. Галузева програма «Плоди і ягоди України - 2017». URL: http://eurowine.com.ua/minisites/fermerhouse/node/251 (дата звернення: 06.05.2020).

7. Галузева Програма розвитку садівництва України на період до 2025року. URL: http://minagro.gov.ua. (дата звернення: 06.05.2020).

8. Урядова програма фінансової підтримки розвитку садівництва, виноградарства та хмелярства 2020. URL: https://agro.me.gov.ua/ua/pidtrimka/sadivnictvo/uryadova-programa-finansovoyi-pidtrimki-rozvitku-sadivnictvavinogradarstva-ta-hmelyarstva-2020 (дата звернення: 06.05.2020).

9. Інститут садівництва Національної академії аграрних наук України. URL: http://sad-institut.com.ua/o_nas.html (дата звернення: 06.05.2020).

10. Національний науковий центр «Інститут виноградарства i виноробства імені B.€. Taїрова». URL: http://www.tairov.com.ua/ (дата звернення: 06.05.2020).

11. Український інститут експертизи сортів рослин. URL: https://sops.gov.ua/tvorce-spivrobitnictvo (дата звернення: 06.05.2020).

\section{References:}

1. Barabash L.O. (2012) Stratehiia innovatsiinoho rozvytku haluzi sadivnytstva [Strategy for innovative development of the horticulture industry]. Zbirnyk naukovykh prats VNAU. Seriia: Ekonomichni nauky, №3(69), pp. 10-14.

2. Boltianska L.O., Andrieieva L.O., Lysak O.I. (2015) Ekonomika pidpryiemstva: navchalnyi posibnyk [Enterprise Economics: textbook]. Kherson: Oldi-plius. (in Ukrainian)

3. Rudytsia S.I. (2012) Rol innovatsii u pidvyshchenni efektyvnosti promyslovoho sadivnytstva [The role of innovation in improving the efficiency of industrial gardening]. Zbirnyk naukovykh prats VNAU. Seriia: Ekonomichni nauky, № 3(69), pp. 190-194.

4. Pyvovar A.M., Pyvovar P.V. (2015) Vplyv NTP na protsesy formuvannia ta efektyvnosti vykorystannia mashynno-traktornoho parku silskohospodarskykh pidpryiemstv. Visnyk ZhNAEU, № 1 (48), vol. 2, pp. 105 - 116.

5. Kornieva I.I. (2016) Derzhavna finansova pidtrymka pidpryiemstv APK: stan ta stratehiia rozvytku [State financial support for agribusiness enterprises: state and development strategy]. Hlobalni ta natsionalni problemy ekonomiky: Elektronne naukove vydannia, vol.14, pp. 802 - 807. Available at: http://global-national.in.ua/archive/14-2016/160.pdf (accessed o6 May 2020).

6. Haluzeva prohrama «Plody i yahody Ukrainy - 2017» [Industry program «Fruits and berries of Ukraine-2017»]. Available at: http://eurowine.com.ua/minisites/fermerhouse/node/251(accessed o6 May 2020).

7. Haluzeva Prohramma rozvytku sadivnytstva Ukrainy na period do 2025roku [Industry program for the development of horticulture in Ukraine for the period up to 2025]. Available at: http://minagro.gov.ua (accessed o6 May 2020).

8. Uriadova prohrama finansovoi pidtrymky rozvytku sadivnytstva, vynohradarstva ta khmeliarstva 2020 [Government program of financial support for the development of horticulture, viticulture and hop growing 2020]. Available at: https://agro.me.gov.ua/ua/pidtrimka/sadivnictvo/uryadova-programa-finansovoyi-pidtrimki-rozvitku-sadivnictva-vinogradarstva-ta-hmelyarstva-2020 (accessed o6 May 2020).

9. Instytut sadivnytstva Natsionalnoi akademii ahrarnykh nauk Ukrainy [Institute of horticulture of the National Academy of agricultural Sciences of Ukraine]. Available at: http://sad-institut.com.ua/o_nas.html (accessed o6 May 2020).

10. Natsionalnyi naukovyi tsentr «Instytut vynohradarstva i vynorobstva imeni V.Ye. Tairova» [National research center «Institute of viticulture and winemaking named after V. E. Tairov»]. URL: http://www.tairov.com.ua/ (accessed o6 May 2020).

11. Ukrainskyi instytut ekspertyzy sortiv roslyn [Ukrainian Institute of plant variety expertise]. URL: https://sops.gov.ua/ tvorce-spivrobitnictvo (accessed o6 May 2020). 
Kolokolchikova Iryna

Poltava State Agrarian Academy

\section{MECHANISM OF IMPLEMENTATION OF STP IN THE BUSINESS ENVIRONMENT OF THE MARKET OF FRUIT AND BERRY PRODUCTS}

The condition for the development of the industry of high-quality fruit and berry products is the introduction of scientific and technological progress. Ukrainian scientists note the importance of the work of scientific institutes and experimental stations to create and maintain an adapted assortment of fruit and berry crops. It is proved that scientific developments are important for the industry; they allow optimal use of the natural-climatic, biological and technological potential of the regions. The stages of implementation of innovative innovations are considered. The main types of innovations are outlined: biological, technical, chemical and technological.

A mechanism for implementing NTP and interacting with the business environment in the market of fruit and berry products is proposed. Implementation of innovations occurs through the interaction of the external and internal environment. The external environment is represented by specialized scientific and government institutions, as well as producers, consumers, and a retail network. The importance of special institutions and the state in supporting and implementing scientific progress was emphasized.

The internal environment for the implementation of scientific developments in the field of horticulture is represented by both basic components: biological, technical, technological, chemical, and additional. It is proposed to expand the internal environment of innovative transformations of information and consulting, scientific and methodological and organic components. The purpose of information and consulting support for fruit and berry producers is to provide systematic, grouped information about innovations, practical experience and economic results. The scientific and methodological component will allow manufacturers to get a justification for the need to implement innovations and gradual implementation of the necessary processes. It is established that this is what is necessary for small businesses, which today produce most of the fruits and berries that have significant difficulties in obtaining information, knowledge about innovations, their implementation.

Also, the reality of today is the development of the market for organic products, which in the horticultural industry is advisable to develop and increase through subsidiary farms. This will make it possible to gradually increase the production of organic fruits and berries, generate demand for these products and give an impetus to the creation and development of the domestic market for organic products.

The interaction of all components of the mechanism for implementing scientific and technological progress will make it possible to accelerate the introduction of innovations in the production sector of large, medium and small businesses, as well as to achieve high quality products and the corresponding economic effect.

Key words: scientific and technical progress, innovation, state support, market of fruit and berry products, business environment.

JEL classification: $\mathrm{O} 13, \mathrm{O} 33$. 